Man and Nature

MAN AND NATURE

L'homme et la nature

L'HOMME ET LA NATURE

\title{
The Massachusetts Superior Court and the American Revolution: The Professionalization of a Judicial Elite, 1740-1775
}

\section{Peter E. Russell}

Volume 1, 1982

URI : https://id.erudit.org/iderudit/1011796ar

DOI : https://doi.org/10.7202/1011796ar

Aller au sommaire du numéro

Éditeur(s)

Canadian Society for Eighteenth-Century Studies / Société canadienne d'étude du dix-huitième siècle

ISSN

0824-3298 (imprimé)

1927-8810 (numérique)

Découvrir la revue

Citer cet article

Russell, P. E. (1982). The Massachusetts Superior Court and the American Revolution: The Professionalization of a Judicial Elite, 1740-1775. Man and Nature / L'homme et la nature, 1, 109-118. https://doi.org/10.7202/1011796ar

Copyright (c) Canadian Society for Eighteenth-Century Studies / Sociéte canadienne d'étude du dix-huitième siècle, 1982
Ce document est protégé par la loi sur le droit d'auteur. L'utilisation des services d'Érudit (y compris la reproduction) est assujettie à sa politique d'utilisation que vous pouvez consulter en ligne.

https://apropos.erudit.org/fr/usagers/politique-dutilisation/ 


\section{The Massachusetts Superior Court and the American Revolution: The Professionalization of a Judicial Elite, 1740-1775}

The Massachusetts Superior Court was in a transitional position in 1750. It represented both the traditional western system of enforcing law and state policy by utilizing the power and prestige of the social elite and a more recent tendency to employ trained legal specialists. This tendency would be fully developed in the nineteenth and twentieth centuries. There was thus a latent contradiction between the concept of a judiciary drawn from the governing class that promoted and gave effect to government policy and one whose participation in the governing process was limited to interpreting the law and applying it to disputes that came before the court. This paper is concerned with the resolution of that dilemma.

Courts frequently played an important part in the politics of pre-industrial western societies, acting as intermediaries between the central power and those who exercised effective local authority. ${ }^{1}$ For instance, the English tribunals which served as the jurisdictional model for the Superior Court of Massachusetts had functioned as an effective link between the two levels of political power in the late sixteenth and seventeenth centuries. ${ }^{2}$ Well-born judges of assize communicated crown policy to local justices who had the primary responsibility for enforcing it, influenced the selection of men to fill those posts, and attempted to mediate county disputes that might hinder the effective administration of justice and government policy. They also provided legal guidance for the numerous lay judiciary, and exercised "the amalgam of coercion and authoritative advice which formed the basis of the judges' control over the rural bench" in the interests of the national government and those who composed it. "The success of domestic policy . . . turned in practice on the existence of reliable media for conveying to provincial agencies the content and implication of relevant legislation and for ensuring that the programmes therein expressed were fully and persistently implemented. . . . This function was most regularly and successfully discharged by the judges of assize." 4

Recent scholarship views the Massachusetts high court in a similar light. Kinvin Wroth argues that "the circuits of the Superior Court brought the authority and image of the central government directly to the counties," and 
"that the courts of Massachusetts were an effective agency of social control in all areas of human conduct on the local level." The high court not only impressed citizens but had the power to enforce its decisions through sheriffs, constables and coroners; those decisions were numerous and seizures of persons and property functioned as vivid reminders of the power of the judiciary and the government it represented. In addition, laws announced by the judges were "constraints upon individual conduct at the stage at which private activity is planned." David Flaherty agrees, noting that judges "were prominent and powerful people both in their local communities and at the provincial level of politics," making especially "active and powerful agents of the central government" in an essentially orderly and well-behaved society. ${ }^{6}$ Like its English predecessors, the Massachusetts bench took full advantage of the opportunity of delivering a charge to the grand jury to educate courtroom crowds on current political and social issues as well as the fundamentals of criminal law. ${ }^{7}$

In pre-Revolutionary Massachusetts, political leadership was exercised by wealthy, educated men from the leading families of seaboard mercantile communities. ${ }^{8}$ Such men were the backbone of government, for they brought to their work as legislators the prestige derived from prominent families, wealth, culture and seats on the county judiciary. ${ }^{9}$ The respect in which they were held was a crucial factor in giving effect to the policies of a provincial government which, lacking significant coercive resources, had to rely on the compliance of the local authorities and populace. ${ }^{10}$ Such cooperation could best be secured by having the colony's laws and policies framed and implemented by men whose authority was readily accepted in the towns. ${ }^{11}$

The same is true of the Superior Court. While commercial towns did not produce the majority of its judges, the long-settled eastern counties did. ${ }^{12}$ In addition, both legislative leaders and high court jurists came from old, socially prominent families whose standing was intimately related to the acquisition of a college education and a seat on the powerful county courts. ${ }^{13}$ Nominations to the principal court of law were thus clearly related to the methods by which the colony was governed.

The mid-eighteenth century was an important period in the evolution of Massachusetts' judicial elite, for access to the Superior Court was increasingly restricted to men from families with several generations of judicial service, and nominees themselves were now generally drawn from those with extensive experience on other provincial tribunals. The growing tendency to appoint experienced judges to the highest court combines with the fact that most governors had some legal background to suggest a deliberate policy, or at least awareness of the importance, difficulty, and perhaps distinctiveness of the judicial function and the qualities needed to perform it well. ${ }^{14}$

Both reliance on members of the established political and social elite and the choice of men with legal expertise were evident in other contemporary western societies as well. In both England and France, major courts were no longer filled with randomly selected representatives of the governing class who held no regular judicial office, functioned sporadically as judges, and were not appointed on the basis of legal skill. Instead, the monarchies chose men to perform an identifiable adjudicatory function on a continuous 
basis, taking into account social origins, professional training, and experience in the application of legal principles. ${ }^{15}$ For instance, eighteenth-century English judges were generally members of influential families and had attended university, trained at the Inns of Court, and practiced law. ${ }^{16}$

Colonial judges in Brazil, appointed by the Portuguese monarchy, were the sons of gentlemen, lawyers, officials or international merchants in the mother country. These jurists possessed university law degrees, had taught or practiced law, served in the bureaucracy or held office in the lower courts before joining the high court. Once in Brazil, they occupied an ambiguous position between the crown and the creole planter elite. ${ }^{17}$ Like Spain, Portugal feared the weakening of royal control that might result from judges' forming close ties with powerful elements in colonial society. ${ }^{18}$ The crown strove to prevent such links but failed to isolate its judges from their environment; they bought property, joined organizations, and befriended and married members of leading Brazilian families. However, the court "never became the creature of any one group in Brazilian society" and generally maintained "institutional autonomy in the face of pressure" from both sides. The home government came to realize the judges' value as a mediating force in conflicts with its often fractious colonists and as an interpreter of crown policies to those whose compliance was essential to their successful implementation. ${ }^{19}$

Because of their general lack of coercive resources, many governments in the early modern period still had to rely on social elites to secure the compliance of the populace in law enforcement. In England, France and Massachusetts, members of the indigenous "better sort" manned the highest courts, while in Brazil the crown employed prominent Portuguese with strong connections to important elements in creole society. Law could best be enforced when the visibly active agents combined the authority of the monarchy with that of the most influential and respected elements in society itself. In addition, governments in England, France and Portugal had long been aware that judges not only had to represent royal authority and the prestige of the ruling class, but to render effective decisions in often complex legal disputes. As a result, their criteria for judicial appointments had come to include the possession of a degree of legal expertise. Massachusetts, the youngest of the four societies, was clearly moving in that direction by the 1760 s.

This increasing emphasis on the Superior Court's juridical function is closely related to the increase in complexity and sophistication that occurred in American law during the eighteenth century. The expansion of settlement and commerce brought more numerous and difficult cases before colonial courts, leading to greater reliance on the complex doctrines of the English common law and a search for lawyers and judges capable of interpreting and applying them successfully.

Superior Court judges heard a very wide range of private disputes, criminal charges and local conflicts as they travelled from county to county. ${ }^{20}$ Their caseload was as heavy as it was varied, for by the time of the Revolution the Court was hearing more than ten times as many actions as it had sixty years earlier. Table 1 illustrates the dramatic increase. 


\begin{tabular}{|lrrrrr}
\hline \multicolumn{7}{c}{ TABLE 1 } \\
CIVIL LITIGATION AND POPULATION, 1710-1773 \\
\hline \multicolumn{7}{c}{$\begin{array}{c}\text { No. } \\
\text { Year }\end{array}$} & $\begin{array}{c}\text { Pct. } \\
\text { Lawsuits }\end{array}$ & Increase & Population & $\begin{array}{c}\text { Pct. } \\
\text { Increase }\end{array}$ & $\begin{array}{c}\text { Lawsuits } \\
\text { Per } \\
\text { Thousand }\end{array}$ \\
\hline 1710 & 83 & & 62,390 & 1.33 \\
\hline 1750 & 1013 & 1120.5 & 188,000 & 201.3 & 5.39 \\
\hline 1773 & 1128 & 11.4 & $235,308^{\mathrm{a}}$ & 25.2 & 4.79 \\
\hline $\begin{array}{l}\text { Overall } \\
\text { Increase }\end{array}$ & & 1259.0 & & & \\
\hline
\end{tabular}

${ }^{\text {a }} 1770$ population.

Source of population figures: Jack P. Greene, ed., Settlements to Society, 1584-1763 (New York, 1966), p. 238; figures derived from U.S. Bureau of Census, Historical Statistics of the United States (Washington, 1960), p.756.

Litigation was clearly increasing much faster than population. This does not mean that resorting to the judicial system was a new activity for Massachusetts colonists - far from it. They had inherited their English forebears' "national addiction to the adversary process" and developed their own multi-level legal system in the seventeenth century. ${ }^{21} \mathrm{New}$ England merchants had long been known for actively continuing the tradition of "the instinctive litigiousness of the Puritan Fathers." 22

Nonetheless, by the middle of the eighteenth century even local contemporaries were complaining of the readiness with which their countrymen went to court. Harvard College President Edward Holyoke spoke in 1741 of their "want of Brotherly Love evident by their quarrelsome, litigious Disposition, and Lawsuits without numbers." ${ }^{23}$ Fifteen years later the legislature remonstrated, not for the first time, that "trials of civil actions, upon appeals and reviews, have been unnecessarily multiplied, to the great charge [expense] and grievance of many of his majesty's subjects." 24

Colonial Americans' growing addiction to the law also attracted the attention of English observers. Attorney General William DeGrey told Parliament, likely in the late 1760s, that American protests would show "how well these Americans are versed in the Crown [criminal] Law. I doubt whether they have been guilty of an overt act of treason; but I am sure they have come within an hair's breadth of it." 25 The more sympathetic Edmund Burke made the famous observation a few years later that in the colonies

all who read - and most do read - endeavor to obtain some smattering in that science [law]. I have been told by an eminent bookseller, that in no branch of his business, after tracts of popular devotion, were so many books as those of the law exported to the Plantations. The Colonists have now fallen into the way of printing them for their own use. . . General Gage . . . states that all the people in his government [Massachusetts] are lawyers, or smatterers in law. ${ }^{26}$ 
Judge Peter Oliver also applied the concept to Massachusetts, writing that "the People of the Province seem to be born with litigious Constitutions . . . [a] general Foible." 27 Twenty-four years on the bench had given him ample opportunity to observe the phenomenon. Pauline Maier, no admirer of the British, agrees with DeGrey, Gage, Burke and Oliver, stating that "in Massachusetts . . . every man thought himself a lawyer."28

Their disputes sent colonists not only to justices of the peace and county courts of common pleas, but to the province's highest court of law, for payment of debts was often delayed and impatient creditors were not reluctant to use the legal system as a collection agency. ${ }^{29}$ Because appeals to the Superior Court were inexpensive and access relatively frequent due to the circuit system, many suitors disappointed at the county level pursued their remedies in the high court.

Massachusetts provincials were contentious but not disorderly under normal circumstances. A disciplined people, they generally kept their conflicts within socially approved bounds, avoiding serious illegal activities in favor of such forums as town meetings and courts of law. (Even riotous group departures from the letter of the law were viewed by participants as measures to give effect to the proper meaning of that law. $)^{30}$ Unlike the situation in New York, serious criminal activity was rare throughout the provincial period, though increasing slightly toward its end. ${ }^{31}$ People generally looked to the law and the courts for preservation of their rights, even against officialdom.

The Superior Court thus functioned as an important agency of social control, giving people an accessible forum in which to resolve their conflicts. Its judges possessed the experience in social, economic, political and legal affairs to deal effectively with a large and complex workload and direct the jury panels in deciding the small proportion of cases that came before them.

In exercising those functions, the bench received considerable assistance from a legal profession and body of law that were coming to resemble those of England more closely. Similar developments were under way in other colonies, for with the growing availability of British law books and trained lawyers, ${ }^{32}$ "colonial common law courts were making a self-conscious effort to replicate the behaviour of their English counterparts." As a result, the eighteenth century was "the era of more sophisticated adoption of the common law." ${ }^{33}$ In Massachusetts these developments "continued relentlessly . . . with a cumulative effect that was momentous." ${ }^{34}$ Not only the Superior Court was affected, for by mid-century both procedural and substantive law in the courts of Middlesex County were coming "to approximate English models." ${ }^{35}$ The transformation was still incomplete in 1775, for Massachusetts retained its traditional easy access to all courts and relatively simple, flexible procedures, ${ }^{36}$ and some areas of law showed little evidence of Anglicization as yet; for instance, divorce law, applied by the governor and council rather than the Superior Court, still "diverged significantly from that of England." ${ }^{37}$ The over-all trend, however, was not toward divergence but toward greater conformity. Massachusetts and its fellow colonies were moving in parallel fashion toward greater reliance on English law, thus requiring the presence of more technically sophisticated high courts. 
It was this juridical aspect of the Superior Court's activities on which contemporaries commented before 1760 . Whether they were unaware of the judges' governmental role, latently hostile to it, or took it for granted as a necessary and proper part of traditional society does not appear in the sources. The latter began with the statute of 1698 which prescribed the oath to be sworn by newly appointed jurists requiring them to "serve our sovereign lord the king and his people . . . and . . . do equal law and execution of right to all people, poor and rich." ${ }_{38}$ Reverend Samuel Moody expressed much the same idea in 1741 when he wrote glowingly of judges ${ }^{39}$

Lynd, Dudley, Remington and Saltonstall,

With Sewall, meeting in the judgment Hall,

Make up a learned, wise and faithful Set

Of God-like judges by God's Counsel met.

Chief Justice Benjamin Lynde was embarrassed by the fulsome tribute; likely he would have preferred the comment of William Douglass, who described the Superior Court as "perhaps the most upright of any in our national Plantations and Colonies." 40 Not all mid-century colonists shared the favorable opinions of Moody and Douglass, however. On April 9, 1752 Judge Benjamin Lynde Jr. "found a small pox letter enclosing scabs and a plaster put into the window of kitchen, with design to infect us." ${ }^{11}$ The governor offered a reward of $£ 500$ O.T. for information leading to the conviction of the "Evil-minded Person" responsible. ${ }^{42}$ The incident was neither punished nor repeated.

The death of Chief Justice Stephen Sewall in September 1760 occasioned several observations on the qualities requisite in a successful judge. An anonymous newspaper correspondent praised the deceased for "the nicest sense of honour, and an uncommon delicacy of conscience . . . wisdom . . . singular fidelity . . . [and] great dignity." ${ }^{33}$ Prominent clergyman Charles Chauncy complimented Sewall for his "quickness of apprehension and a capacity to look thoroughly into a subject." ${ }_{44}$ His fellow cleric Jonathan Mayhew added the late judge's "great decorum in the court" and the "strict impartiality ... [of] the knowing lawyer, and the upright judge." 45 The members of Massachusetts' highest court were expected to be men of integrity, impartiality, intelligence, learning and dignity.

The Revolutionary years from 1760 to 1774 brought about the erosion of the respect in which the Court was held. The bench was involved in a series of crises that aligned it with Lieutenant Governor Thomas Hutchinson, the royal customs service, the British army, and the ministry and Parliament in London. Its critics argued vociferously that, instead of upholding the constitution and the law, the judges appeared to abet their violators and to be willing to profit from such complicity. Fortunately the high court's acts elicited not only intemperate denunciations but articulate criticism that probed the nature of the proper relationship between judiciary, politics and society. Not surprisingly, radical spokesmen rejected the bench's traditional role as an elite instrument of government because of its potential for conservative political partiality. The judges' persistent adherence to that concept of their function caused the administration's critics to attempt to 
educate the public on the importance of having a judiciary that could maintain its integrity and impartiality by eschewing political controversy in favor of the adjudication of legal disputes. These arguments had sufficient effect by 1774 to cause the people to repudiate the Superior Court for a position that it had taken almost reflexively, thus demonstrating perhaps a greater awareness of recent changes in the judiciary's social role than the judges themselves possessed. ${ }^{46}$

Seventeenth-century English judges had suffered similar fates in revolutionary situations. Their emphasis on the legal rights of the crown in the 1630 s soon proved unacceptable to Parliament. The latter was unwilling to believe that the law could favor its opponents and therefore blamed the men who applied it. ${ }^{47}$ Although there was yet no formal doctrine of the separation of powers, there was "a growing feeling that some kind of demarcation could and should be made" between the judicial and political spheres. ${ }^{48}$ It is not clear whether the post-Restoration judiciary had learned this lesson. On one hand, its important role as political intermediary between capital and provinces was taken over by other agencies, notably the lords lieutenants of the counties. ${ }^{49}$ On the other hand, judges were highly visible partisans again in the 1680s, "securely identified . . . with James II and with the prerogative excesses which had brought on the Revolution." What seems most likely is that revulsion at the conduct of James's judicial henchmen like Chief Justices Jeffreys and Scroggs reinforced the trend toward defining a new and less partial role for the high courts. "Retribution [against such men] did not . . . usher in immediately a new era of independent and politically nonaligned judges, ${ }^{50}$ but it probably ensured that judicial behavior moved closer to that standard in the eighteenth century. ${ }^{51}$

Thus the mid- and late eighteenth century saw Massachusetts share in important legal trends that were also evident in other western societies. The higher judiciary was becoming more of a distinct and specialized profession with an increasingly high level of expertise in the complex techniques of interpreting and applying the law. This development was a necessary precondition to the emergence of a "formative era" in the early nineteenth century when American judges played a major role in creating and adapting institutions appropriate to a dynamic and expanding society. ${ }^{52}$

The appearance of a more technically skilled and less overtly politicized judiciary also suggests a society approaching "modernity." One feature of this widely discussed process was the change from the "convergence of roles" characteristic of the seventeenth century to a social system that "multiplies and separates them." ${ }^{53}$ In the legal sphere, modernization has usually been seen in the organization of hierarchical court systems, greater use of rules "ascertainable from written sources by techniques that can be [rationally] learned and transmitted," selection of trained experts to operate the system, and a tendency to greater technical complexity. In short, "the task of finding law and applying it to concrete cases is differentiated in personnel and technique from other governmental functions." ${ }^{54}$ Processes of this sort were going on in late colonial Massachusetts and other colonies as well. While the Bay Colony's judicial system was not quite the "strikingly modern" and "remarkably sophisticated" organization described by Hiller Zobel, ${ }^{55}$ even less 
was it the rigid conservator of a static, Puritan-dominated social order characterized by William E. Nelson. ${ }^{56}$

The work and personnel of the Superior Court reflected significant processes of legal, social and political change which Massachusetts shared with other sectors of western society. ${ }^{57}$ The Bay Colony, once quite separate and aloof, had become an integral part of a larger and modernizing culture.

\author{
Peter E. Russell \\ The University of Western Ontario
}

\title{
Notes
}

' Stuart B. Schwartz, Sovereignty and Society in Colonial Brazil: The High Court of Bahia and its Judges, 1609-1751 (Berkeley, 1973). Mark A. Burkholder \& D.S. Chandler, From Impotence to Authority: The Spanish Crown and the American Audiencias, 1687-1808 (Columbia, Mo., 1977). Leon G. Campbell, "A Colonial Establishment: Creole Domination of the Audiencia of Lima During the Late Eighteenth Century," Hispanic American Historical Review, 52 (1972), 1-25. Franklin L. Ford, Robe and Sword: The Regrouping of the French Aristocracy After Louis XIV (Cambridge, Mass., 1953, rpt. New York, 1965).

2 J.S. Cockburn, A History of English Assizes, 1558-1714 (Cambridge, Eng., 1972), especially the Introduction and ch. $8 \& 9$.

3 Ibid., ch. 8; quotation from p. 171.

4 Ibid., 179. W.J. Jones, Politics and the Bench: The Judges and the Origins of the English Civil War (London, 1971), pp. 18-19.

5 L. Kinvin Wroth, "Possible Kingdoms: The New England Town From the Perspective of Legal History," American Journal of Legal History, 15 (1971), 320-322. Hereafter cited as AJLH.

"David H. Flaherty, "Review of William E. Nelson, Americanization of the Common Law," University of Toronto Law Journal, 26 (1976), 111-112.

7 Cockburn, pp. 67-69. John D. Cushing, "The Judiciary and Public Opinion in Revolutionary Massachusetts," in George Athan Billias, ed., Law and Authority in Colonial America (Barre, Mass., 1965), pp. 168-186.

${ }^{8}$ Robert M. Zemsky, "Power, Influence and Status: Leadership Patterns in the Massachusetts Assembly, 1740-1755," William \&̊ Mary Quarterly, 3rd Ser., 26 (1969), 502-520. To the same effect are Edward M. Cook, Fathers of the Towns: Leadership and Community Structure in Eighteenth-Century New England (Baltimore, 1976) and Richard D. Brown, Revolutionary Politics in Massachusetts: The Boston Committee of Correspondence and the Towns, 1772-1774 (Cambridge, Mass., 1970, rpt. New York, 1976).

9 John J. Waters, The Otis Family in Provincial and Revolutionary Massachusetts (New York, 1975), pp. viii-ix. Waters \& John A. Schutz, "Patterns of Massachusetts Colonial Politics," WMQ. 3d ser., 24 (1967), 567. John M. Murrin, "Anglicizing an American Colony: The Transformation of Provincial Massachusetts" (unpub. Ph.D. diss., Yale Univ., 1966), pp. 265-266.

${ }^{10}$ David H. Flaherty, "Law and the Enforcement of Morals in Early America," Perspectives in American History, 5 (1971), 201 -253. See also Brown, pp. 1-4 for a briefer discussion.

$"$ On a larger scale, the British government recognized the value of acting through locally prominent men in New England, for nearly half of the royally appointed governors there were native to their provinces. (In other mainland royal colonies the figure was one in eight or ten.) Such men were almost always members of leading families, Harvard graduates and possessed of intellectual capacity and interests - Leonard W. Labaree, "The Royal Governors of New England," Colonial Society of Massachusetts, Publications, 32 (Transactions, 1933-1937), $120-131$.

12 The careers of all Superior Court judges appointed between 1692 and 1774 are analyzed in Peter E. Russell, "His Majesty's Judges: The Superior Court of Massachusetts, 1750-1774" (unpub. Ph.D. diss., Univ. of Michigan, 1980), ch. 2 \& Biographical Appendix. 
${ }^{13}$ Ibid. John M. Murrin, "The Legal Transformation: The Bench and Bar of Eighteenth-Century Massachusetts," in Stanley N. Katz, ed., Colonial America: Essays in Politics and Social Development (Boston, 1971), pp. 423-425. Charles Robert McKirdy, "Lawyers in Crisis: The Massachusetts Legal Profession, 1760-1790" (unpub. Ph.D. diss., Northwestern Univ., 1969), pp. 39-40.

14 Russell, pp. 36, 39.

is John P. Dawson, History of Lay Judges (Cambridge, Mass., 1960), pp. 1-4, 69-83, 129-136, 274-280, 293-299, and Oracles of the Law (Ann Arbor, 1968), pp. 3-12, 29-49, 306-314, 339-341, 358-362.

16 Peter E. Russell, “A Profile of the English Superior Court Judiciary, 1714-1775" (unpub. paper, Univ. of Michigan, 1974).

17 Schwartz, pp. 283-313.

18 On Spanish America, see Burkolder \& Chandler, From Impotence to Authority, and Campbell, "A Colonial Establishment."

19 Schwartz, pp. 78, 171-190, 265-267, 280-281, 313-343; quoted portion at 184.

20 The analysis that follows is based on the Superior Court Record Books for 1710, 1730, 1750 \& 1773 in the office of the Clerk of the Supreme Judicial Court, Suffolk County Court House, Boston, and on the Minute Books for 1750, 1757, 1763, 1768 \& 1773 .

${ }^{21}$ Hiller B. Zobel, "The Pompeii of Paper," Boston Bar Journal, 22, 7 (1978), 20. Hereafter cited as $B B J$

22 Bernard Bailyn, The New England Merchants in the Seventeenth Century (New York, 1964), p. 165.

${ }^{23}$ Edward Holyoke, The Duty of Ministers (Boston, 1741).

${ }^{24}$ Preamble of an Act for Further Regulating the Course of Judicial Proceedings, Province Laws, 1756-1757, ch. 28, in Ellis Ames et al., eds., Acts and Resolves of the Province of Massachusetts Bay, 1692-1780, 21 vols. (Boston, 1869-1922).

${ }^{25}$ Quoted by George G. Wolkins in "Daniel Malcom and Writs of Assistance," Mass. Historical Society, Proceedings, 58 (1924-1925), 22. Society hereafter cited as MHS.

${ }^{26}$ Quoted in Alan McKinley Smith, "Virginia Lawyers, 1680-1776: The Birth of an American Profession" (unpub. Ph.D. diss., Johns Hopkins Univ., 1967), pp. 59-60.

${ }^{27}$ Origin and Progress of the American Rebellion, eds. Douglass Adair \& John A. Schutz (Stanford, 1975), p. 27.

${ }^{28}$ From Resistance to Revolution: Colonial Radicals and the Development of American Opposition to Britain, 1765-1776 (New York, 1974), p. 133.

29 Robert J. Brink, “Boston's Great Anthropological Documents,” BBJ, 22, 7 (1978), 12.

${ }^{30}$ Pauline Maier, "Popular Uprisings and Civil Authority in Eighteenth-Century America," WMQ, 3d ser., 27 (1970), 3-35. John Phillip Reid, "In a Defensive Rage: The Uses of the Mob, the Justification in Law, and the Coming of the American Revolution," New York University Law Review, 49 (1974), 1043-1091.

${ }^{31}$ Douglas Greenberg, Crime and Law Enforcement in the Colony of New York, 1691-1776 (Ithaca, 1974). David H. Flaherty, "Crime and Social Control in Provincial Massachusetts," paper read at the Annual Meeting of the Organization of American Historians, April 1975.

32 Richard B. Morris, Studies in the History of American Law (2d ed., 1958, rpt. New York, 1974) and "Legalism Versus Revolutionary Doctrine in New England," New England Quarterly, 4 (1931), 195-215.

${ }^{33}$ Stanley N. Katz, "The Politics of Law in America: Controversies Over Chancery Courts and Equity Law in the Eighteenth Century," Perspectives in A merican History, 5 (1971), 263, 272.

${ }^{34}$ Murrin, "Anglicizing an American Colony," 151.

${ }^{35}$ Hendrik Hartog, "The Public Law of a County Court: Judicial Government in Eighteenth-Century Massachusetts," $A J L H, 20$ (1976), 297-298, 302.

${ }^{36}$ G.B. Warden, "Inequality and Instability in Eighteenth-Century Boston: A Reappraisal," Journal of Interdisciplinary History, 6 (1976), 615.

${ }^{37}$ Nancy F. Cott, "Divorce and the Changing Status of Women in Eighteenth-Century Massachusetts," WMQ, 3d ser., 33 (1976), 612.

${ }_{38}$ Province Laws, 1698, ch. 23.

${ }^{39}$ Quoted in The Saltonstall Papers, 1607-1815, ed. Robert E. Moody, MHS, Collections, 80 (1972), 79.

${ }^{40}$ Benjamin Lynde Sr., Diary, 1690-1742, ed. Fitch E. Oliver (Boston, 1880), pp. 111-112. 
William Douglass, Summary, Historical and Political . . of the British Settlements (Boston, 1749 , rpt. New York, 1972), I, 517-518.

${ }^{41}$ Benjamin Lynde Jr., Diary, 1721-1780, ed. Fitch E. Oliver (Boston, 1880), p. 175.

${ }^{42}$ Proclamation, May 28, 1752 (Boston, 1752).

${ }^{43}$ Boston Evening Post, Sept. 22, 1760.

${ }^{44}$ Quoted in John Eliot, Biographical Dictionary (Boston \& Salem, 1809), p. 420.

${ }^{45}$ Discourse Occasioned by the Death of the Honourable Stephen Sewall (Boston, 1760). See to the same effect Judge Addington Davenport's obituary in Boston Evening Post, Apr. 19, 1736.

${ }^{46}$ The extensive sources on which this paragraph is based are analyzed in Russell, "His Majesty's Judges," ch. 4.

47 Jones, pp. 13, 20-21, 129-129, 137-139, 147-148.

48 Ibid., pp. 16-17.

${ }^{49}$ Cockburn, pp. 184-187.

so Ibid., p. 259.

${ }^{51}$ Ibid., pp. 184-187.

52 Nineteenth-century developments are ably discussed in Roscoe Pound, The Formative Era of American Law (Boston, 1938); James Willard Hurst, The Growth of American Law: The Law Makers (Boston, 1950), Law and the Conditions of Freedom in the Nineteenth-Century United States (Madison, Wis., 1956), Law and Social Process in United States History (Ann Arbor, 1960); Leonard W. Levy, The Law of the Commonwealth and Chief Justice Shaw: The Evolution of American Law, 1830-1860 (Cambridge, Mass., 1957); Charles M. Haar, ed., The Golden Age of American Law (New York, 1965); Stanley I. Kutler, Privilege and Creative Destruction: The Charles River Bridge Case (Philadelphia, 1971); Morton J. Horwitz, The Transformation of American Law, 1780-1860 (Cambridge, Mass., 1977).

53 Thomas Bender, Community and Social Change in America (New Brunswick, N.J., 1978), p. 61.

54 Marc Galanter, "The Modernization of Law," in Myron Weiner, ed., Modernization: The Dynamics of Growth (New York, 1966), pp. 155-156.

ss Hiller B. Zobel, "Law Under Pressure: Boston, 1769-1771," in Billias, ed., pp. 187-188.

${ }^{56}$ William E. Nelson, Americanization of the Common Law: The Impact of Legal Change on Massachusetts Society, 1760-1830 (Cambridge, Mass., 1975), pp. 16-63.

57 Recent literature stressing the importance of transatlantic links in the eighteenth century includes R.R. Palmer, The Age of the Democratic Revolution: A Political History of Europe and America, 1760-1800 (Princeton, 1959); Bernard Bailyn, The Ideological Origins of the American Revolution (Cambridge, Mass., 1967); John Clive \& Bernard Bailyn, "England's Cultural Provinces: Scotland and America," WMQ 3rd ser., 11 (1954), 200-213; Michael Kraus, The Atlantic Civilization: Eighteenth-Century Origins (Ithaca, 1949); Carl Bridenbaugh, Mitre and Sceptre: Transatlantic Faiths, Ideas, Personalities and Politics, 1689-1775 (New York, 1962); I.K. Steele, Guerrillas and Grenadiers: The Struggle for Canada, 1689-1760 (Toronto, 1969); Louis Gottschalk \& Donald Lach, Toward the French Revolution: Europe and America in the Eighteenth-Century World (New York, 1973). The field is surveyed by Jack P. Greene, I.K. Steele and others in the Journal of Imperial and Commonwealth History, 8 (1980). 